\title{
Respiratory System Findings End Date Time
}

National Cancer Institute

\section{Source}

National Cancer Institute. Respiratory System Findings End Date Time. NCI Thesaurus.

Code C123957.

The date and time a respiratory system assessment has concluded. 